\title{
Rivaroxabankezelés mellett kialakult bal pitvari fülcsethrombus sikeres kezelése direkt trombininhibitorral
}

\author{
Szegedi Nándor dr. - Gellér László dr. - Tahin Tamás dr. \\ Merkely Béla dr. - Széplaki Gábor dr. \\ Semmelweis Egyetem, Általános Orvostudományi Kar, Városmajori Szív- és Érgyógyászati Klinika, Budapest
}

\begin{abstract}
A szerző́k a 62 éves, rivaroxabannal antikoagulált férfi betegnél perzisztens pitvarfibrilláció miatt pulmonálisvénaizolációt terveztek. A preoperatív transoesophagealis echokardiográfia során bal pitvari fülcsethrombus jelenlétét mutatták ki. Thrombophilia irányában végzett vizsgálataik alapján a beteg heterozigótának bizonyult metilén-tetrahidrofolát-reduktáz-génmutációra. Feltételezték, hogy ebben az esetben a direkt trombininhibitor hatékonyabb antithromboticus hatással bírhat, ezért dabigatranra váltottak. Két hónapnyi direkt trombininhibitor kezelés és folsavpótlás mellett a thrombus feloldódott. A szerzók kiemelik, hogy pitvarfibrilláló betegnél adekvát rivaroxabanterápia mellett is kialakulhat bal pitvari fülcsethrombus. Jelen eset felveti annak a lehetőségét, hogy a metilén-tetrahidrofolátreduktáz-génmutáció csökkentheti a Xa faktor inhibitorok hatékonyságát. Az esettanulmány alapján dabigatranra való csere hatékony lehet a bal pitvari fülcsethrombusok feloldásában. Orv. Hetil., 2016, 157(4), 154-156.
\end{abstract}

Kulcsszavak: bal pitvari fülcsethrombus, feloldódás, rivaroxaban, dabigatran, MTHFR-gén-mutáció

\section{Successful direct thrombin inhibitor treatment of a left atrial appendage thrombus developed under rivaroxaban therapy}

The authors present the history of a 62-year-old man on continuous rivaroxaban therapy who was scheduled for pulmonary vein isolation due to persistent atrial fibrillation. Preoperative transesophageal echocardiography detected the presence of left atrial appendage thrombus. Thrombophilia tests showed that the patient was heterozygous carrier of the methylene-tetrahydrofolate reductase gene mutation. The authors hypothesized that a direct thrombin inhibitor might exert a more appropriate effect against thrombosis in this case and, therefore, a switch to dabigatran was performed. After two months of anticoagulation with the direct thrombin inhibitor and folic acid supplementation the thrombus resolved. The authors underline that thrombus formation may develop in atrial fibrillation even if the patient is adequately treated with rivaroxaban. This case suggests, that methylene-tetrahydrofolate reductase gene mutation may modulate the efficacy of direct Xa factor inhibitors. According to this case history, dabigatran may be an effective therapeutic option in resolving established thrombus.

Keywords: left atrial appendage thrombus, resolution, rivaroxaban, dabigatran, MTHFR mutation

Szegedi, N., Gellér, L., Tahin, T., Merkely, B., Széplaki, G. [Successful direct thrombin inhibitor treatment of a left atrial appendage thrombus developed under rivaroxaban therapy]. Orv. Hetil., 2016, 157(4), 154-156.

(Beérkezett: 2015. november 3.; elfogadva: 2015. november 19.)

\section{Rövidítések}

Ao $=$ aorta $; \mathrm{LA}=$ bal pitvar; $\mathrm{LAA}=$ bal pitvari fülcse $; \mathrm{MVT}=$ mélyvénás thrombosis; MTHFR = metilén-tetrahidrofolátreduktáz; TEE $=$ transoesophagealis echokardiográfia
Jelenleg nem áll rendelkezésre szakmai iránymutatás arra vonatkozóan, mi a helyes terápiás lépés abban az esetben, ha rivaroxabant szedő betegnél fülcsethrombus alakul ki. 


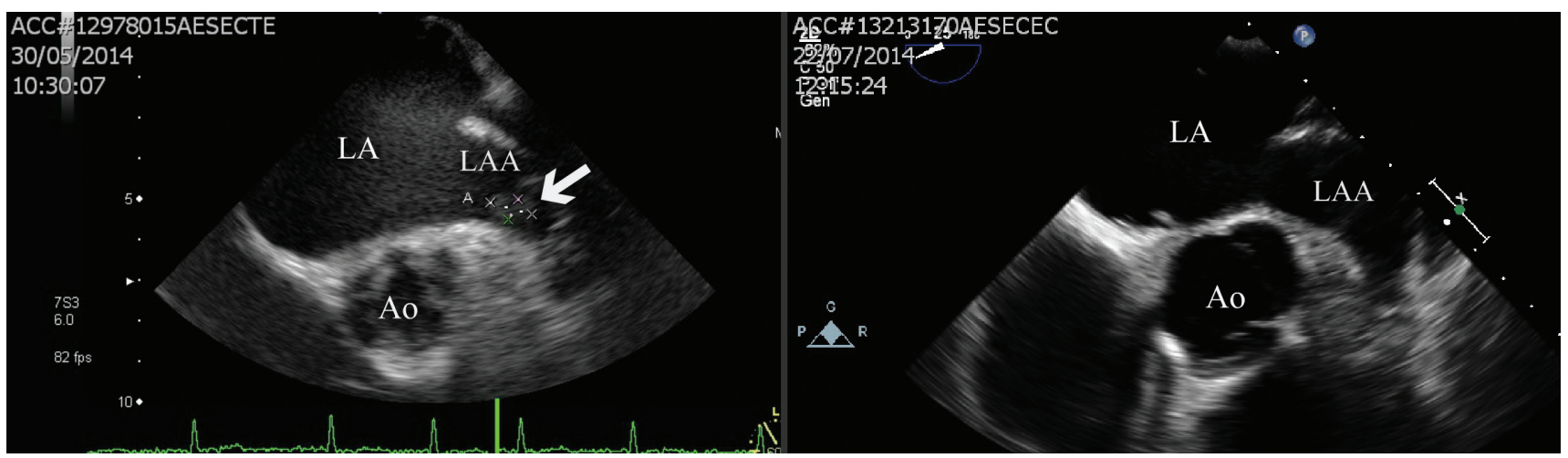

1. ábra

A beteg transoesophagealis echokardiográfiás képei. Bal oldalon a rivaroxabanhatásban detektált fülcsethrombus látható (nyíl), jobb oldalon a két hónapnyi dabigatran-antikoagulációt követő állapot látható, ahol a fülcse üres

Ao $=$ aorta LA $=$ bal pitvar; $\mathrm{LAA}=$ bal pitvari fülcse

\section{Esetismertetés}

A 62 éves férfi betegünknél terápiarefrakter perzisztens pitvarfibrilláció miatt terveztünk pulmonálisvéna-izolációt. Anamnéziséből mélyvénás thrombosis (MVT), magasvérnyomás-betegség és cukorbetegség emelendő ki. A páciens magas thromboemboliás rizikó $\left(\mathrm{CHA}_{2} \mathrm{DS}_{2}-\right.$ VASc score 2) miatt antikoaguláns kezelésben részesült, napi $20 \mathrm{mg}$ rivaroxaban formájában. Klinikai rutinunknak megfelelően transoesophagealis echokardiográfiát (TEE) végeztünk az ablatio elótt, amely során bal pitvari fülcsethrombus jelenlétét mutattuk ki ( 1 . ábra, bal oldal), így a beavatkozást elhalasztottuk. Tekintettel a frissen felfedezett thrombusra és az anamnézisben szereplő MVT-re, thrombophiliateszteket végeztünk: emelkedett homocisztein- és folsavszint mellett kimutattuk, hogy a páciens heterozigóta metilén-tetrahidrofolát- (MTHFR-) mutációra.

Az esetek többségében az MTHFR genetikai polimorfizmusa enyhe-közepes fokú hyperhomocysteinaemiát okoz. Az emelkedett homociszteinszint miatt csökken a protein C-aktivitás. Ez utóbbi miatt az Va és VIIIa faktorok kevésbé gátlódnak, és a protrombin-trombin átalakulás fokozódik, így a véralvadás egyensúlya prokoaguláns irányba tolódik el $[1,2]$. Feltételezésünk szerint egy olyan antikoaguláns, amely a fent említett lépés után gátolja az alvadási kaszkádot, hatékonyabb lehet MTHFRmutáció esetén.

Ebből a megfontolásból a beteget a továbbiakban direkt trombininhibitorral $(2 \times 150 \mathrm{mg}$ dabigatran $)$ antikoaguláltuk. Két hónapig tartó dabigatranterápia és folsavpótlás után ismét TEE-vizsgálatot végeztünk (1. ábra, jobb oldal): a bal pitvari thrombus feloldódott, és az ablatiót is sikeresen elvégeztük, szövődmény nélkül.

Habár több klinikai vizsgálat és metaanalízis kimutatta, hogy a rivaroxabankezelés ugyanolyan hatékony és biztonságos, mint a warfarin, acenokumarol vagy dabigatran $[3,4]$, amint azt esetünk is mutatja, közepes thromboemboliás rizikóval bíró pitvarfibrilláló betegek- ben rivaroxabanterápia mellett is kialakulhat intracardialis thrombus [5].

Intézményünkben pitvarfibrilláció-ablatióra 2014-ben 440 beteg volt előjegyezve, közülük $80(18,2 \%)$ részesült folyamatos rivaroxabankezelésben. Bal pitvari fülcsethrombus 3 esetben volt kimutatható $(3,7 \%)$. Bár Yadlapati és mtsai 53 betegból egynél sem találtak fülcsethrombust [6], itt az esetszám igen alacsony a mi betegpopulációnkhoz képest. Adatbázisunkban a fülcsethrombus előfordulási gyakorisága viszonylag magas rivaroxabankezelés mellett, aminek fontos gyakorlati mondanivalója lehet: felhívja a figyelmet a preprocedurális képalkotó modalitások (úgymint TEE-vizsgálat, intracardialis echokardiográfia, illetve CT-angiográfia) jelentőségére és további nagy betegszámú klinikai vizsgálatok szükségességére.

\section{Megbeszélés}

Tudomásunk szerint ez az elsô esetbemutatás rivaroxabankezelés mellett kialakult fülcsethrombusról MTHFRmutációval bíró betegnél. Jelen közleményünk egy MTHFR-mutációra heterozigóta beteg esetét mutatja be, akinél hónapokon át tartó, rendszeresen szedett, terápiás dózisú rivaroxaban ellenére bal pitvari fülcsethrombus alakult ki. Dabigatranra váltottunk, emellett 2 hónap alatt a fülcsethrombus feloldódott. Az eset klinikailag fontos kérdéseket vet fel a Xa faktor inhibitorral antikoagulált betegekkel kapcsolatban. Az eset azt sugallja, hogy az MTHFR-mutáció módosíthatja a rivaroxaban hatékonyságát, és mivel a populáció nem jelentéktelen része MTHFR-mutáció-hordozó, az esetbemutatásunk felveti ezen kérdéskör további vizsgálatának szükségességét [7].

Esetbemutatásunk tanulsága alapján a dabigatranra való csere hatékony lehet ilyen esetekben, bár erre vonatkozóan további irodalmi adat jelenleg nem áll rendelkezésre. Másfelől, korábbi esetbemutatások azt mutatták, hogy K-vitamin-antagonistával antikoagulált, illetve an- 
tikoagulációban nem részesülő betegnél a rivaroxabanra való csere hatására feloldódhat a fülcsethrombus. Ezek az adatok, az általunk közölttel együtt, a direkt Xa faktort gátló rivaroxaban metabolizmusának individuális különbségeit világítja meg $[8,9]$.

Anyagi támogatás: A publikáció a Bolyai János Kutatási Ösztöndíj és az OTKA K 105555 támogatásával készült.

Szerzôi munkamegosztás: Sz. N., Sz. G.: Az adatok gyüjtése, a kézirat megszerkesztése. G. L., T. T., M. B.: A kézirat revíziója, a végleges verzió jóváhagyása. A cikk végleges változatát valamennyi szerző elolvasta és jóváhagyta.

Érdekeltségek: A szerzőknek nincsenek érdekeltségeik.

\section{Irodalom}

[1] Brezovska-Kavrakova, J., Krstevska, M., Bosilkova, G., et al.: Hyperhomocysteinemia and of methylenetetrahydrofolate reductase (C677T) genetic polymorphism in patients with deep vein thrombosis. Mater. Sociomed., 2013, 25(3), 170-174.

[2] Rozen, R.: Genetic predisposition to hyperhomocysteinemia. Deficiency of methylenetetrahydrofolate reductase (MTHFR). Thromb. Haemost., 1997, 78(1), 523-526.
[3] Dillier, R., Ammar, S., Hessling, G., et al.: Safety of continuous periprocedural rivaroxaban for patients undergoing left atrial catheter ablation procedures. Circ. Arrhythm. Electrophysiol., $2014,7(4), 576-582$.

[4] Caldeira, D., Costa, J., Ferreira, J. J., et al.: Non-vitamin K antagonist oral anticoagulants in the cardioversion of patients with atrial fibrillation: systematic review and meta-analysis. Clin. Res. Cardiol., 2015, 104(7), 582-590.

[5] Wasmer, K., Köbe, J., Dechering, D., et al.: CHADS(2) and CHA(2)DS(2)-VASc score of patients with atrial fibrillation or flutter and newly detected left atrial thrombus. Clin. Res. Cardiol., 2013, 102(2), 139-144.

[6] Yadlapati, A., Groh, C., Passman, R.: Safety of short-term use of dabigatran or rivaroxaban for direct-current cardioversion in patients with atrial fibrillation and atrial flutter. Am. J. Cardiol., 2014, 113(8), 1362-1363.

[7] Steiner, T., Böhm, M., Dichgans, M., et al.: Recommendations for the emergency management of complications associated with the new direct oral anticoagulants (DOACs), apixaban, dabigatran and rivaroxaban. Clin. Res. Cardiol., 2013, 102(6), 399-412.

[8] Hammerstingl, C., Pötzsch, B., Nickenig, G.: Resolution of giant left atrial appendage thrombus with rivaroxaban. Thromb. Haemost., 2013, 109(4), 583-584.

[9] Saito, S., Tomita, H., Kimura, ., et al.: Reduced smoke-like echo and resolved thrombus in the left atrium with rivaroxaban therapy in an acute cardioembolic stroke patient. J. Stroke Cerebrovasc. Dis., 2014, 23(6), 1747-1749.

(Széplaki Gábor dr., Budapest, Városmajor u. 68., 1122 e-mail: szeplaki.gabor@gmail.com)

\section{Medizinisches Zentrallabor Altenburg GmbH \& Co. KG Am Waldessaum 8 D-04600 Altenburg \\ www.mzla.de \\ labor@mzla.de}

Wir suchen ab sofort:

\section{Facharzt/Fachärztin für Mikrobiologie und Infektionsepidemiologie.}

Sie verfügen über eine vollständige Befähigung und Approbation als Arzt/Ärztin sowie über eine Bescheinigung über den Abschluss der fachärztlichen Ausbildung für Mikrobiologie und Infektionsepidemiologie. Goethezertifikat Deutsch Niveaustufe B2 erforderlich.

\section{Medizinisch-technische Laborassistent/-assistentin. Deuschkenntnisse sind erforderlich.}

Bewerbungen auf Deutsch oder Ungarisch an obige Adresse oder labor@mzla.de.
Azonnali kezdéssel keresünk:

\section{Mikrobiológust/bakteorológust,}

amennyiben teljes értékủ orvosi képesitéssel és engedéllyel, valamint a szakorvosi képzés sikeres befejezését igazoló bizonyitvánnyal, mint mikrobiológus és bakteorológus rendelkezik. Goethezertifikat B2-es német nyelvvizsga szükséges.

\section{Orvosi laboratóriumi asszisztens}

munkatársat.

Német nyelvtudás szükséges.

Pályázat benyújtása német vagy magyar nyelven a fenti címre vagy a következő e-mail címre:

labor@mzla.de 